\title{
The politics of health: urban regulation and planning in the Spanish colonies during the Eighteenth century
}

Book or Report Section

Accepted Version

Murray, C. (2017) The politics of health: urban regulation and planning in the Spanish colonies during the Eighteenth century. In: Slater, T. R. and Pinto, S. M.G. (eds.) Building Regulations and Urban Form, 1200-1900. Routledge, Abingdon, UK, Chapter 11. ISBN 9781472485373 Available at http://centaur.reading.ac.uk/50839/

It is advisable to refer to the publisher's version if you intend to cite from the work. See Guidance on citing.

Publisher: Routledge

All outputs in CentAUR are protected by Intellectual Property Rights law, including copyright law. Copyright and IPR is retained by the creators or other copyright holders. Terms and conditions for use of this material are defined in 
the End User Agreement.

www.reading.ac.uk/centaur

\section{CentAUR}

Central Archive at the University of Reading

Reading's research outputs online 


\title{
10. The Politics of Health: Urban Regulation and Planning in the Spanish Colonies during the Eighteenth Century
}

\author{
Claudia Murray
}

During the eighteenth century in colonial Latin America a complete restructuring of the Spanish city network was introduced under the Bourbon reforms. ${ }^{i}$ At regional level, new administrative areas were created in order to facilitate communications and trade. At the urban level, the transformation of nodal cities such as Mexico City, Lima and Buenos Aires reflected not only the hierarchical importance attached to these centres but also the monarchy's concerns around novel and enlightened ideals of health and sanitary conditions in large urban agglomerations.

New planning regulations encouraged the regularisation and paving of streets. Parks, promenades and the building of hospitals and educational institutions dedicated to health were also encouraged and promoted as symbols of salubrious and civilised environments in an era where public ignorance and poverty were synonymous with pestilence and diseases. But under this new banner of health, the implementations of public works also helped the Bourbons to regain control of the urban population which was growing and expanding in the colonies. City planning gave the authorities an opportunity to improve land taxation. These were measures aimed at trying to recover the Empire's finances which were severely damaged after decades of the Hapsburg excesses (EXPLANATION NEEDED(in a note?). How the Spanish bureaucrats implemented and imposed the new regulations and the resistance encountered from powerful groups and elites in colonial Latin America is the focus of this chapter.

\section{Spanish urban control : a hierarchical scale of cities and societies}

The process of colonisation in the Spanish empire was structured around a network of cities for controlling and exploiting the new dominions. The method of colonisation has been attributed to the Spanish experience during the Reconquista when Spain recovered territories in the Iberian Peninsula from the Moors by using a system of frontier cities to secure and hold gained positions. ${ }^{\text {ii }}$ The idea of conquering by settling connects urban development with politics and, in a monarchical Spain with a strict hierarchy, it was a process that was used by cities to gain power and privileges from the Crown. 
Cities were ranked by a structured political administration all over the kingdom. In the colonies, large vice-regal capitals enjoyed higher privileges than smaller provincial cities, which had lower ranked officials and a longer bureaucratic chain of administration to reach the Crown. ${ }^{\text {ii }}$ The network of cities representing the Spanish state in the New World is different to the modern day network of cities where the diffusion of innovations and the movement of population enjoy a high degree of freedom. In contrast, the urban system during imperial Spain in the eighteenth century, was deeply hierarchical with a national metropolis dominating the country while major metropolitan centres dominated regional subsystems of cities which in turn dominated their local areas and small towns; this is a pattern that is still followed by the majority of Latin American countries today, except that in general, freedom of international trade allows for a more dynamic exchange of ideas and goods than in colonial times.

The geographical location of government bodies representing the Crown needed to be close to commercial activities, particularly in an era when communications could only be speeded-up by face-to-face encounters. Individual cities were therefore linked through a network of trade and commercial connections in hierarchical order with Madrid at the top of the hierarchy. Political, economic or ideological changes were made by the Crown and cascaded downwards to the cities, towns and villages of the empire. This hierarchical urban system was the one proposed as early as 1521 by the Spanish Trinitarian friar Alonso del Castillo, who asserted that the city was the noblest of human assemblages and that a kingdom was properly composed of hierarchically arranged cities or republics. ${ }^{\text {iv }}$

\section{The Bourbon reforms and the Spanish Enlightenment}

The end of the Habsburg dynasty in 1700, and the ruin of Spain, was preceded by the writings of several European intellectuals who theorised on the reasons for the fall of the Spanish empire and questioned the extension of any given empire and the impact of migration from the mother country to the colonies. The Italian theorist Giovanni Botero wrote as early as 1607 that 'Spain had sent to America not the superfluous, but those who might be useful and even necessary, thereby losing not the excessive or corrupted blood, but that which is pure and healthy, thus draining and weakening the provinces [in Spain]. ${ }^{\mathrm{v}}$ Botero's ideas as well as those of other intellectuals, had an influence on the Spanish enlightened elite that had also begun to question the limits of the empire. It was said among them that 'God and nature had placed a limit on all empires beyond which they have to return back as do the waves. ${ }^{\text {vi }}$ Thus, and towards the end of the Hapsburg era the once glorious Spanish empire had fallen into decay and even Spanish intellectuals were admitting the need for change. This state of affairs is what awaited the arrival of the first Bourbon king, Philip V (1702- 
1746). If the new monarch wanted to rebuild the kingdom, the complete state apparatus needed to be reformed and the main barrier to this was the powers and privileges of the nobility in peninsular Spain as well as the colonies. This meant that the Crown had to claw back power from the quasiindependent provinces, cities and states that were permitted to develop under the Habsburg dinasty.

With the introduction of enlightened theories of government in Spain and other European countries, monarchical ruling and scientific knowledge in Europe merged in order to achieve a more rational form of government where internal policies aimed to improve educational opportunities, health, social conditions and economic life. ${ }^{\text {vii }}$ But despite the liberal aim of these policies, enlightenment ideas in Spain were adopted to justify the centralization of power. ${ }^{\text {viii }}$ Still, from a socio-economic perspective, the enlightenment proved to be one of the best sources of inspiration for changes in state policies that the Bourbon Spanish ministers used. In general terms, the enlightenment sought to provide benefits for all members of society or at least for the majority. The monarch (and the viceroys in the colonies) had a responsibility towards his subjects in the sense that he was expected to deliver security and prosperity in exchange for loyalty and obedience. ${ }^{\mathrm{ix}}$ In the mercantilist eighteenth-century societal, prosperity meant trade and profits; ${ }^{\mathrm{x}}$ which was one reason why the commercial monopoly that Spain maintained with its colonies changed after 1778, and henceforth a certain degree of freedom was introduced.

To summarise, the enlightened Bourbon reforms involved changes in the organisation of government that aimed to concentrate power in the hands of the king. The scientific approach and questioning of previous theories paved the way to diminish Church involvement in state politics. It also meant the rebuilding of the navy, as this was considered essential to maintain an overseas empire and for the control of contraband trade. The process was gradual, first introducing reforms in 1765 under Phillip V to open up new routes and ports of trade between Spain and the colonies. Successive Bourbon kings contributed at different stages to the agenda - Philip's policy was followed by that of Ferdinand VI, who, in a more peaceful fashion, sought to gain the support of the British monarchy to reduce contraband in Spanish America. Nevertheless, it was not until the ascent of the third Bourbon king, Charles III (1759-1788) that reform reached the colonies when the system of intendants was introduced between 1764 and 1786.

\section{The Intendancy system}

The system of intendants was first introduced to Spain under Philip V in order to find a way of 
controlling the army's expenditure in each province of the Peninsula. These first intendants, known as intendentes de ejército, were appointed as early as 1711 . The success of this experiment led to the extension of the intendants' functions in the Ordinance of 4 July 1718 , when these officials were given the responsibility for administering the finance of the whole province to which they were appointed, which included the financing of public works. The system encountered problems and resistance from local bureaucrats, particularly in Peru and Mexico where the resistance came from the more than 200 officials (corregidores and alcaldes) operating in those regions. ${ }^{\mathrm{xi}}$ Nevertheless, due to the proven success of the intendants in controlling army finances, intendancies were established under Ferdinand VI in October 1749. ${ }^{\mathrm{iii}}$ In the colonies, intendants were known as superintendents when they were appointed to a vice-regal capital, and were supposed to collaborate with the viceroy but were also directly in communication with the Crown, as was the viceroy. Both authorities were also in control of urban and regional matters in a system that was designed to control the powers of both figures (superintendents and viceroys). A kind of checks and balance arrangement between two officials which created personality clashes, bringing in turn many problems and thereby delaying urban works. ${ }^{\text {xiii }}$

In order to institute an enlightened administrative reform of this magnitude in the colonies, knowledge of the local finances and economic resources as well as accurate population censuses from all cities were needed. To assess the urban and rural situation in the colonies Philip V's most important minister, José Patiño, sent the engineer Jorge Juan and the humanist Antonio de Ulloa to the northern region of South America in 1735. Whilst their stated mission was to assist a group of French scientists in measuring an arc of the meridian at the Equator, their secret mission was to report to the government on the conditions in the colonies. Their Noticias Secretas (secret news) was the result of that mission. This would not be the first or last report the monarchy commissioned from its colonies. Due mainly to local complaints about corrupt bureaucrats, several visitadores- visitors were appointed to conduct inspections of the functioning of government. These visitadores brought valuable information to the Crown about conditions in the colonies that helped government advisors in the drawing up of new policies.

The sources of inspiration for colonial government were Campillo y Cosío's Nuevo Sistema de Gobierno Económico para la América (new system for economic governance in the Americas, 1743). Cosío had been a minister of the treasury in 1741 and, subsequently, Minister of Marine, War and Minister of the Indies, so he was considered an expert in colonial matters and their economy. Cosío considered Spain to be in a lamentable state and was convinced that the solution relied on commerce. ${ }^{\text {xiv }}$ He believed that Indians should be turned into useful vassals for the state, meaning that they should be encouraged to become participants in the economy by becoming 
producers and consumers. This was a complete departure from previous Spanish policies that, thus far, had attempted to minimise Indian contact with Europeans. Spain now realised the economic potential of the Indian population in the colonies to be transformed into consumers for Spanish goods, which was why the Crown opposed the growth of industries in the colonies. The idea now was that Spain and its colonies would become a single corporate entity where the monarch was its head and symbol of state power that provided security for all corners of the empire. The Crown thus guaranteed commerce as long as it was able to keep armed forces patrolling the land and seas. Therefore trade had to expand in order to provide the necessary revenues to keep the Spanish troops and fleet in place. But this entailed a stricter control of the urban city network, particularly in all commercial routes and ports of the empire, so that no taxes were avoided, which, if it could not be guaranteed, then Cosío's proposal of an expanded commerce would only continue to benefit other nations and the illegal trade.

But even if enlightened ministers were full of ideas for the Empire, the reforms did not truly reach the colonies until the appointment of José de Gálvez to the Secretaría de las Indias. Gálvez had spent six years as a visitador in New Spain (Mexico), from 1765 until 1771. During this time he acquired an accurate knowledge of the situation in the colonies. His first measure was to increase the centres of administration, thus far concentrated between Mexico City and Lima. Gálvez argued that there were new areas with large contraband activities that needed better monitoring, thus, as well as the Viceroyalty of the Río de la Plata (1776), the captaincies general of Venezuela (1777) and Chile (1778) were also created. ${ }^{\mathrm{xv}}$

Henceforth, the control of economic life in colonial cities across the empire was in the hands of the intendants. The hierarchical status of networks was expanded with the addition of these new centres. For example, in the case of the River Plate area, the viceroyalty was subdivided into intendancies with Buenos Aires named as the superintendancy to which all the others were subordinate. But as had happened in the peninsula with the Bourbon reform, imposing a new administration on the colonies proved difficult. Creole elites in the colonies were administering their regions with a substantive amount of autonomy imposing their private interests upon the easily corrupted Spanish governors and corregidores. ${ }^{\mathrm{xvi}}$ The Crown was losing power to Creoles in places that, by the late eighteenth century, were key economic centres of the empire. ${ }^{\text {xvii }}$ The new administrative framework imposed by José de Gálvez led to a de-Creolisation of politics, or the drastic reduction of non-Spaniards in positions of power. In order to achieve this, the sale of high office was officially ended in 1750 and soon bureaucracies in all the main colonial capitals were headed by peninsular Spaniards. In the period 1751-1808, of the 266 appointments in American audiencias only sixty-two went to Creoles, compared with 200 to peninsulars. 
To summarise, in economic terms, the Bourbon reforms in the colonies aimed to boost revenues for the Crown at a time when mineral production in South America had begun to diminish. The value of other products and other economic activities, such as in the case of the River Plate the production of hides, showed the Crown the economic possibilities of the colonies that had been neglected or considered only from a defensive and political perspective. This prompted a change in Spain's commercial policies that opened more ports for trade. This brought more business to port cities and merchants took advantage of the situation. The case of Buenos Aires is paradigmatic as it became the fastest growing city in the empire at the time. ${ }^{\text {xiii }}$ Its merchants' growing wealth made possible the construction of better quality houses in the city as these men were able to commit more capital to building private dwellings and were looking for ways to display their wealth. In addition, the prosperity that trade brought to the area attracted new arrivals that built new houses, which either filled empty city plots or contributed to the expansion of the city. ${ }^{\text {xix }}$ There was also a new demand for property, some of it of high quality that was created by the arrival of new government officials, businessmen and travellers. Buenos Aires is just an example of the effect that the new economic policies were having on cities. Other urban centres were growing just as fast and the logical consequence of this change was the need to rethink an apparatus dominated by corrupt urban oligarchs who misappropriated public funds and monopolised municipal offices.

\section{The Ordenanza de Intendentes (1782)}

By 1750 the power of the Church all over Europe had begun to decline in favour of a new ideology based on rational thought. The programme of the Enlightenment was the 'disenchantment of the world' ${ }^{\mathrm{xx}}$ or the search for a more rational explanation of the world and its natural forces. It was characterised by a mistrust of religion and traditional authority, and by an optimism that human progress could be achieved through education and a generally utilitarian approach to society, which was visible in public health measures to reduce crime and control disease. In this context the state took measures to place under surveillance 'a whole range of urban developments, constructions, and institutions. ${ }^{\text {xxi }}$ The author also explains that the well-being of subjects was not only a state concern, but that society in general should also become involved through organisations such as charities and the Church that also attempted to organise health policies.

The distinction between the state health concern and that of society and the Church was that the latter had philanthropic reasons while the former had a clear agenda to preserve the labour force as economically active. With the great demographic expansion of the eighteenth century, Foucault 
argues, came the necessity for incorporating the growing population into the apparatus of production. Therefore the development of medicine during the eighteenth century came with the need for selecting the healthy and the sick, the strong and the weak, in order to determine those with greater prospect of survival so that they could be turned into useful subjects. Foucault's observations concur with the new political plans presented by Cosio in 1743, who intended to turn indigenous groups in the colonies into consumers of Spanish goods. It can be argued therefore that keeping the population healthy was part of maintaining the imperial corporation economically active and in a continuous state of growth.

How connected the ideas of economic growth, population control and healthy cities were can be seen in the document that guided all bureaucrats in the colonies, the Ordenanza de Intendentes issued in 1782 for the Viceroyalty of the River Plate. This was the first document drafted by the Crown to establish the intendant system in the colonies, it was followed by other similar documents for Peru (1784), and New Spain (1786) and it was used by local authorities to draft documents for the control of their own regions. ${ }^{\text {xxii }}$ According to the Ordenanza de Intendentes (1782), all intendants in the colonies were responsible for the collection of taxes and duties and for the control of the countryside to promote agrarian activities that could in turn improve commerce. They were also to control all aspects of urban life known as 'policía', which was an extensive concept that ranged from urban works to social behaviour in public places and included the collection of crucial data for administration such as censuses and maps. The document is an example of eighteenth century urban regulation at a time of geographical changes in the empire and of mass migrations to urban centres.

In the section dedicated to Policía, the main concern of the Crown is about communications and transport. ${ }^{x i i i}$ The Crown urged intendants to collect accurate information on the state of all roads, bridges, posadas (guest houses) and to envisage ways of improving their conditions to facilitate trade. ${ }^{\text {xxiv }}$ The section also urges authorities to improve road signs to speed up communications. At a time when the resources from gold and silver mines were dwindling, the Crown wanted to collect data on exquisiteces (local delicacies) that could be sold in Europe, classifying them in the context of best routes to nearest ports for export. The utilitarian measures also included the classification of people according to their state of health and economic potential for society. Therefore vagrancy was targeted; those fit to work should do so in agricultural fields, or join the army. Those unfit for both activities should be taken to hospices, or if they were criminals, to the mines or prisons, for hard labour activities. The new regulations thus imposed a classification with the direct aim of improving the Crown's coffers, the health concern was a by-product of the 
policies but not its main objective.

The Ordennazas also regulate the spatial organisation of urban areas. In all cities of all sizes in the colonies, four main points are highlighted as most important in the Policía section: cleanliness, ornament, uniformity and street paving. ${ }^{\mathrm{xxv}}$ As previously argued ${ }^{\mathrm{xxvi}}$ the issue of ornament can be related to a desire to control taste and to limit ostentation by the growing merchant class which were seen by the Spanish elite as a threat to the establishment. But the other three sections in the Ordennazas of cleanliness, uniformity and street paving were directly connected to health and therefore form the focus of the next section.

\section{Cleanliness, uniformity and street paving}

As Buenos Aires was the capital city of the Viceroyalty of the River Plate, created in 1776, the first signs of enlightened urbanism in the colonies were seen in this city. ${ }^{\text {xxvii }}$ The enlightened bureaucrats that arrived in the city soon began to propose and implement urban changes which mainly focused on street paving, lighting and waste collection. ${ }^{\text {xxviii }}$ But it was not until the arrival of the second Superintendant of Buenos Aires, Francisco de Paula Sanz (1783-1788) that substantial changes began to occur. Soon after his appointment, Sanz claimed that due to the disorderly manner in which many houses had been built and the lack of regulation, the urban landscape of Buenos Aires now lacked uniformity. ${ }^{\text {xxix }}$ He therefore made planning permission for private and public building compulsory. Henceforth no building, no foundation, no wall, no door to the street would be built without the government's permission. And he named two surveyors who were responsible for inspecting sites and ensuring that buildings were constructed following the uniformity required by laws. ${ }^{\mathrm{xx}}$ From 1784 when planning permissions were made compulsory until 1792, over 200 applications for building were made in Buenos Aires, which included new projects and extensions and even small changes such as the replacement of doors and windows that faced the street. ${ }^{\text {xxxi }}$

The tendency towards regularisation that Sanz wished the city to have was not an objective exclusive to Spanish colonial cities but an ideal of many eighteenth-century urban spaces. The overall aim was to achieve a compact and organised aggregate of buildings with a clear cut definition of spaces, rather than a mere agglomeration of houses randomly and widely scattered in the landscape. A growing concern about the unity of the urban landscape began to appear among many European thinkers of the time. A prominent architectural theorist noted in 1753 that towns in France were 'a mass of houses crowded together haphazardly without system, planning or design. ${ }^{\text {xxxii }}$ While in Spain, another recognised authority, Abbot Antonio Ponz, in 1772 published 
a work entitled Viaje de España, where he advocated order that would create uniform cities. ${ }^{\text {xxiii }}$ In the Spanish colonies, the report sent by the governor of Manila informing the government of the general plan of the city particularly with regard to the lack of uniformity of the façades, is indicative that the trend to uniformity had also reached the colonies. According to this governor, the street line in Manila was a collection of different houses where it was permitted to mix noble and elegant buildings with poorly built cabins and huts. The governor went on to say that these huts were built on an irregular plan that not only damaged the geometrical layout of the city, but it was also a health hazard. ${ }^{\text {xxiv }}$ Without a doubt, in Europe and the Spanish American colonies during the Enlightenment, ideal cities were ordered, with unbroken street lines and houses built to conform to a certain style and of similar standard. ${ }^{\mathrm{xxx}}$

In Buenos Aires, the introduction of planning permissions for private buildings was consistent with the ideas of Abbot Ponz, who in his already cited work declared that no government should allow complete freedom for people to build their dwellings because no citizen had the right to 'make the city look ugly' adding that it was up to the government to give permission for building on a particular site and in a particular style. ${ }^{\text {xxxi }}$ This work of Ponz was well known in the Spanish world including Buenos Aires and was frequently used and cited in urban matters. ${ }^{\text {xxxvii }}$ It is interesting to point out that with his remarks Ponz was not only empowering governments in questions of aesthetics - they were the ones deciding what made the city look 'ugly'- but he was also encouraging them to issue new laws to control and educate citizens in stylistic matters. The system of planning permissions inspired by Ponz and implemented by Sanz for Buenos Aires thus appears, as the ultimate in government control of the colonial urban environment. To understand such an intrusion, the policy needs to be considered in the context of Enlightenment thought, where ideas like the 'benefit for all"' prevailed over individuality. Therefore all citizens were called upon to regulate their façades in order to display in the whole, a magnificent city, characterised by unity and order which, in turn, would send rival nations and neighbouring powers a strong message of the country's harmony. This moral call to all citizens became more apparent at a time when travelling and the emergence of the press increased the circulation of urban chronicles and images. Absolutist governments did not overlook the advantages of such publicity and the subject became so important for states that philosophers were involved. In France, Voltaire pointed out to the authorities in his essay The embellishment of Paris (1749) that it was time for those who ruled the most important capital in Europe to make it the most comfortable, and the most magnificent of cities. ${ }^{\text {xxxviii }}$ Meanwhile in Madrid, it was argued that before the paving of the streets commenced in the 1760s, the condition of them 'put the city to shame' in front of other European courts. ${ }^{\text {xxxix }}$ 
Once the regulations for planning permissions were in place in Buenos Aires, the government began controlling private architecture and fitting it to its ideal of a city. Legal procedures for granting planning permission in Buenos Aires followed more or less the same pattern. First the petitioner wrote to the superintendent - who was the authority responsible for handling planning permission applications - attaching plans and a brief description of the project. The authorities then sent the surveyors to measure the land and ensure that neighbours would not be affected by the new construction. With the information gathered the surveyors wrote a report, noting whether there were any problems in which case, they pointed out how they could be solved. Once the surveyors were satisfied with the application, they wrote a favourable report to support the applicant, who was finally granted permission by the superintendent.

Buenos Aires was the first capital to receive the Ordenanzas and the first to implement them. Soon other cities followed suit but the smoothness with which new measures were implemented in Buenos Aires are in contrasts to the problems in older and more developed capitals in the colonies. According to chroniclers, by 1768 Mexico City's streets were mostly paved and were considered to be very healthy given their ample width (allegedly three carts could run side by side through some of them). ${ }^{\mathrm{xl}}$ But it seems that paving was not evenly executed as individual owners were responsible for paving the front of their properties and this was done in all manners, with a variety of materials and at different levels. As a consequence paving was uneven, with hazardous steps and potholes, and was ideal ground for collecting stagnant water. This was hardly the uniform and healthy streets that the Ordenanzas promoted. The periphery of Mexico City, according to the commentator Antonio de Ulloa, was in an even worst condition. Here the grid had given way to a disordered and irregular arrangement of houses - similar to the description given by the governor of Manila - which needed the attention of the authorities. Mexico City also had the problem of constant floods given the fact that it was built upon a lagoon. Ulloa describes the health hazards presented by the many lakes surrounding the city and although he praises the engineering work of Huehuetoca to drain the lake, he points out that the city's infrastructure needed more attention and higher public investment. It was easy, then, to apply the Ordenanzas in a relatively young city such as Buenos Aires, which was receiving new wealthy bureaucrats willing to spend money on the construction of their private dwellings and support street paving with their taxes, but Mexico city was populated mainly by established families who considered that they had already contributed to street improvements through previous taxation; while new arrivals were only temporarily appointed officers, mostly living in rented accommodation. The periphery of the city, where the main problem was located, was populated by a large agglomeration of lower classes who had more pressing concerns than the regularisation of the streets as they needed first to build their houses with more durable materials, 
therefore the Ordenanzas were not always followed so thoroughly. Mexico City was constantly battling against floods and, as correspondence from the time testifies, the shortage of funds prevented the authorities from making any improvements. ${ }^{x l i}$ The city had to wait to the following century, after independence, to make any progress in solving the health hazard posed by floods.

Despite the lack of funds, authorities of all colonial capitals looked for cost effective ways to make urban improvements and better living conditions. Particularly as this was seen as a sign of paternalistic wisdom, for at this time health, social order and security were regarded as the path to a more civilised and healthy life. The French urban theorist Pierre Patté was particularly concerned with these issues, encouraging governments to act and save cities from their 'pathological' state. xlii In the hierarchical urban system of Spain, officials were eager to demonstrate, and meticulously to record, their paternalistic wisdom, as this could help them secure a better post and thus climb another step up the hierarchical career ladder.

So, if street paving, draining and flood controls were proving too costly, most authorities during this time approved and successfully delivered less costly and relatively shorter term improvements such as building public parks and promenades. This guaranteed a connection to health as the idea was that strolls around gardens and controlled natural environments were good for the spirit and health of individuals. But equally, in an era of mass migration, these walks were a space for social encounters and recognition. They were places where strangers in a city could meet and display a strict code of conduct and make gestures that were used to express feelings among strangers. Park and promenade encounters were meant to last only a moment and be kept public. ${ }^{\text {xliii }}$ So promenades were important in keeping social contact and improving urban manners, as well as controlling the growing merchant class, keeping them under the watchful eye of the local aristocracy. In Madrid the Paseo del Prado was developed under Charles III which was reputed to be 'the best in Europe. ${ }^{x l i v}$ In the colonies, an important capital like Lima for example had two, the Navona de Lima and the Paseo de los Descalzos. ${ }^{x l v}$ Both developed under Viceroy Amat, who became famous for the improvements he made to the capital during his term of office $(1761$ - 1776), and was later described by Carrió de la Vandera who remembered him as a 'genius, superior to all other viceroys in matters of civilisation and good manners. ${ }^{\text {xlvi }}$ His efficient mandate in one of the highest offices in the colonies earned him a good retirement and lifetime recognition in his home town of Barcelona in Spain.

The second Viceroy of Buenos Aires, Don Juan José de Vértiz y Salcedo, proposed to build a public walk or alameda next to the river. However, due to a lack of funds, work on the alameda of 
Buenos Aires only started in 1792 under Viceroy Nicolás de Arredondo - eight years after Vértiz's original proposal. But records show that there were several complaints from neighbours stating that the proposed alameda was encroaching into their private land. Arredondo rejected all claims and ordered the owners to modify their private dwellings according to the division lines imposed by the town's surveyors. ${ }^{\text {xlvii }}$ The example of the alameda of Buenos Aires illustrates the financial struggle that even a small public work could face as the walk was less than 100 metres long. Furthermore, it shows the success of the Crown in legalising land titles when plot owners were also seeing the value of defending their land against the invasion of local government public works. The Crown was therefore increasing land taxation, but was simultaneously giving power to private individuals.

\section{Provision of health services}

The royal tribunal of Protomedicato was first established in Spain in 1593 by the Catholic Monarchs to formalise the profession of the physicians and control their activities and

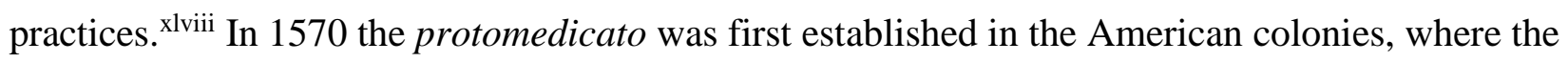
system followed the hierarchical rank of cities, therefore it was first introduced in Lima and Mexico City and later in Buenos Aires after the creation of the Viceroyalty. All other protomedicatos were subordinated to those established in the main capitals. ${ }^{\text {xlix }}$ Historically, most midwives, pharmacists and barber-surgeons based their practices on traditional knowledge brought from Spain, particularly during the mid-Habsburg period when most treatises were written. The introduction of the Bourbon reforms brought an emphasis on education and also the commercialisation of health, with many looking for new plants and native medicines that could provide new treatments to be later sold to other nations. But despite the Bourbons' interest in education and the professionalisation of local healers, their efforts faced many problems as they crossed the Atlantic. One of those problems was related to the salaries of the protomedicatos who soon began to profit from licences and fees for practicing in certain areas which included curanderos (healers). The issue of salaries was a recurrent problem in many offices in the colonies, as the usual path to attract the nobility to remote positions was to offer the possibility of increasing their meagre state wages by the potential gains of running their offices (i.e. taxation, licences, etc). Another problem faced by the health system in the colonies was availability of knowledge as remote regions had practically no access to medical education. Furthermore, the official legislation prohibited the lower castes from entering the medical profession, limiting the practice to a small Creole elite or to peninsular Spaniards. Mestizos gradually appeared towards the end of the colonial period as army surgeons, but their potential help was not widely exploited as pureza de sangre (blood cleanness or the ability to demonstrate Spanish roots with no racial mix) was needed in order to treat patients from the upper classes. Finally, as the function of the 
protomedicato in the colonies took more and more judicial functions - in charge of cases of mal praxis for example - other professions such as lawyers became involved. Such was the case of the protomedicato in Cuba which was presided over by a lawyer. This state of affairs, coupled with the potential profits for practicing licences, made the role of protomedicatos in the colonies increasingly political and their appointment was only given by the Viceroys.

In all capital cities protomedicatos operated in a particular way and had different privileges and functions. In Buenos Aires for example, Viceroy Vertiz (in office during 1778-1784) created the potomedicato for the new capital, which had the typical licensing functions as well as responsibility for education, but with the addition of the control of urban health. The setting of the protomedicato in this city was therefore accompanied by a Bando de Aseo, Limpieza y Policia de Buenos Aires (regulations for urban sanitation). In these Vertiz set out the basis for waste disposal (including aguas servidas or human sewage ) and set up a waste collection system. Additionally, and in accordance to the Ordenanzas, Vertiz also opened an orphanage and children's hospital, a women's prison and a women's hospital and a hospice for beggars. Finally he set up the first university in Buenos Aires which included the teaching of medicine. ${ }^{1}$ This helped his officials to classify the population between the healthy and the sick, the useful and the vagrants; and to locate them spatially within the city layout.

In Peru, the role of Dr Hipolito Unanue (1755-1833) was crucial in the dissemination of practices through the Mercurio Peruano, a journal that displayed the Peruvian enlightenment. In this city, discussions and disagreements on how to train physicians led to a secession between doctors and surgeons and the creation of the Sociedad Patriotica del Monte Pio de Los Cirujanos, a society of surgeons which provided an intellectual base to support professionals who advocated for practice rather than training from books. ${ }^{\text {li }}$ For training doctors, apart from the University of San Marcos, the School of Medicine and Surgery of San Fernando was created. But if Peru was the most enlightened capital in terms of education, Mexico was at the forefront of hospital specialisation. According to accounts of the time, by 1768 Mexico City had a population of 140,000 with ten hospitals and one hospice for the indigent. Hospitals were meticulously classified between race and caste, with hospitals having special wings for Spaniards, natives, blacks and the mixed races.

Advances in hospital medical specialisation developed in Europe also reached the colonies. Some specialised institutions began to appear, for example, to treat infectious diseases; others for the terminally ill and for mental disorders. Still their specialisation must be considered in the context of the time. All hospitals had access to a physician and a nurse, but most were mainly places to 
offer help to those in need. Indian hospitals were usually in isolated locations and some combined a variety of functions (pharmacy, residency of the surgeon, cemetery and even rooms for rent to residential and commercial tenants not necessarily related to hospital functions. ${ }^{\text {lii }}$

\section{Conclusions}

Did the Ordenanzas, the regularisation of the streets, the parks, the formalisation of the medical profession and the classification of hospitals improved health conditions in the colonies during the last part of the eighteenth century? It can be said for certain that advances in knowledge accompanied the design of hospitals, which began to display specialised areas including segregation wings for those with infectious diseases, and special rooms for surgeries and baths for hot water treatments. Even laundry rooms were classified separating clothing and linen according to user's illnesses. But the pureza de sangre and other elitist practices prevented the transmission of new knowledge and advances to the lowers classes which were the majority of the population. As a result malnutrition and endemic disease were common towards the end of the century and even after the 1900s. Sanitation programmes had little effect and again issues of class were the reason of their inefficiency. For example, in 1789 a Spanish order banned burials in churches, but many cities, including Lima, failed to adapt to the new regulation as elites viewed their burial places as a connection with status and power. To avoid conflict many times Viceroy's frequently chose to suspend articles of the Ordenanzas that did not suit them and 'played the game' by waiting years through requesting clarification from Spain, usually passing the problem to their successor.

The enlightened concern for medicine and urban works bettered the quality of life for some but did not control the spread of epidemics which would not be solved until the early nineteenth century. But the Ordenanzas certainly restored the Crown's coffers to health. The new spatial division of the colonies helped the Spanish authorities to collect more localised information on its people and objects of trade. Once the monarchy acquired a more accurate account of the state of its dominions, an army of bureaucrats was put in place physically to organise transportation of goods and collection of taxes. Land was a commodity as was the dwindling mineral reserves, so the regularisation of urban plots was imperative in order to levy accurate land taxes. Healthy individuals were separated from the sick and those able to work were ordered to do so. Indians were turned into consumers and producers and more began to migrate to cities which were seen as centres of civilised and healthy living, but in reality were a trap for increased taxation. In time, the political appointment of protomedics and the barriers for non elites into the medical profession, only added to the mounting discontent of the Creoles who were seeking to ferment rebellion in the colonies. 
Spatially, they were improvements in the urban fabric as streets were gradually paved and house frontages consolidated, filling up empty plots in the grid. Still this betterment of the public space relayed on the willingness of the new comers, particularly merchants, who saw possibilities of settling and creating new businesses or adjusting their old ones to the new economic administration imposed by the Bourbons. The Crown's investment in public works and in bettering urban sanitation remained mainly an ideal on paper; particularly in consolidated cities like Mexico and Lima. Buenos Aires offered more opportunities because of its relatively young age compared to the others. It was therefore the experimental ground were to test new urban regulations which were thought firstly in Europe but tested in the colonies.

\section{Endnotes}


i The Bourbon Reforms (1707-1810), as will be explained later in the chapter, were a series of administrative and economic changes introduced in Spain and the colonies by the new monarchy in order to restore the economy that was badly damaged after decades of mismanagement and reckless expenditure during the last years of previous rulers, the Hapbsburgs (1516-1700).

ii Richard M. Morse, 'The Urban Development of Colonial Spanish America,' in The Cambridge History, Volume 2: Colonial Latin America, ed. Leslie Bethell (Cambridge/New York: Cambridge University Press, 1965, 65-104.

iii Frédéric Mauro, 'Urban Preeminence and the Urban System in Colonial America,' in Urbanization in the Americas from its Beginnings to the Present, ed. Richard P. Schaedel, Jorge E Hardoy, Nora Scott Kinzer (The Hague: Mouton Publishers, 1978), 249-69.

iv Quoted in Morse, 'The Urban Development,' 71 (see note 2).

${ }^{v}$ Quoted in Anthony Pagden, Lords of All the Word: Ideologies of Empire in Spain, Britain and France C.1500-1800 (New York: Yale University Press, 1998), 106.

${ }^{\text {vi }}$ Quoted in Pagden, Lords, 16 (see note 5).

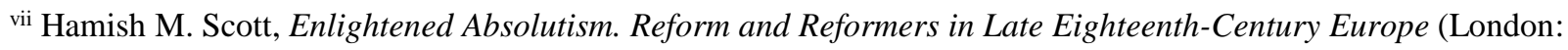
Basingstoke, 1990).

viii John Lynch, Bourbon Spain, 1700-1808 (Oxford: Basil Blackwell, 1989).

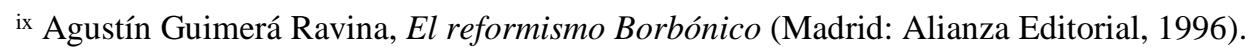

x Peggy K. Liss, Atlantic Empires: The Network of Trade and Revolution, 1713-1826 (Baltimore: John Hopkings UP, 1983).

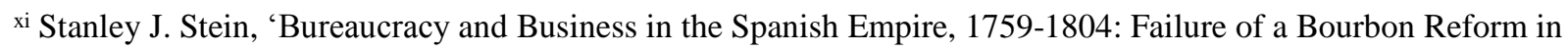
Mexico and Peru,' Hispanic American Historical Review 61-1 (1981): 2-28.

xii John Lynch, Spanish Colonial Administration, 1782-1810. The Intendant System in the Viceroyalty of the Río de la Plata (New York: Greenwood Press, 1969).

xiii Claudia Murray, 'Disciplining Buenos Aires' Private Architecture during the Late Eighteenth Century,'Architectural History 51 (2008): 137-60.

xiv José Martínez Cardós, ‘Don José del Campillo y Cossío,' Revista de Indias 119-122 (1970): 501-42.

${ }^{x v}$ Lynch, Bourbon (see note 8).

${ }^{\mathrm{xvi}}$ The Spanish Crown began to sell offices in the 1630s, treasury offices in 1633, corregimientos in 1678, and judgeships in audiencias in 1687, and by 1700 even the office of viceroy. This system of quick profits at a time when the Crown most needed to increase revenues would prove, as John Lynch explains, a long-term loss. As the Creoles increased in number and positions of power, local interests prevailed over those of the Crown. By the early eighteenth century, the few remaining peninsulars in official position in the colonies were compelled to compromise and negotiate with locals instead of ruling and being obeyed (Lynch, Bourbon, 333-334 (see note 8)). Horst Pietschmann, 'Burocracia y corrupción en hispanoamérica colonial,' Nova Americana 5 (1982): 11-37, explains that the Bourbon reforms and the intendancy system reduced corruption although in New Spain under the viceroys Branciforte and Iturrigaray the level of corruption became again notorious. The author also argues that corruption was a system that allowed the functioning of the colonies and that the commercial developments of some areas would have otherwise been impossible. This necessary system, according to him, explains the more or less permanent tension between the Spanish state, the local bureaucracy and the colonial society.

${ }^{x v i i}$ During the early colonial period, commercial activity was mainly located in those regions formerly controlled by the Aztec and Inca empires. However, the eighteenth century saw the rise of interests in peripheral areas, such as the 
Caribbean islands, the Pampas next to the River Plate, the lands in Central Chile, the hinterland of Caracas and the Mexican mines north of the river Lerma. All these areas were formerly inhabited by Indian societies far less structured than the Incas and Aztecs, and in some cases, the land was still inhabited by hostile groups unwilling to submit to Crown authority. In these peripheral areas the workforce was mainly wage-labourers recruited from the mixed races known as castas, the Creole community, or in some other regions, African slaves were imported. But in all peripheral zones, it was the eighteenth-century merchants and entrepreneurs who provided the wages or the credit for slaves and for wage-labourers. The Crown was not involved in supporting private enterprise and these groups therefore considered that they owed little to the Crown. David A. Brading, 'Bourbon Spain and its American Empire,' in The Cambridge History of Latin America, ed. L. Bethell, vol. 1 (Cambridge: Cambridge University Press, 1984), 289-440. xviii Murray, 'Disciplining Buenos Aires' (see note 13).

${ }^{\text {xix }}$ As a reference here it should be pointed out that according to the census of the population ordered by the Governor of Buenos Aires in 1744 the population was 12,044 people including all social classes. Nicolas Besio Moreno, Buenos Aires puerto del Río de la Plata y capital de la Argentina: estudio crítico de su población 1536-1936 (Buenos Aires: Editorial Buenos Aires, 1939), 326. By 1770 and according to the report given by the postal director appointed by the Crown to the region, the population in Buenos Aires at the time was 22,065 inhabitants. Alonso Carrió de la Vandera, El Lazarillo de los ciegos caminantes (Buenos Aires: Emecé, 1997), 40. Population figures from printed sources during this period are sparse and in many cases only give the number of families rather than head counts so they are provided here as illustration and should be considered with caution.

${ }^{x x}$ Max Horkheimer and Theodor W. Adorno, Dialectic of the Enlightenment (London: Verso, 1997), 3.

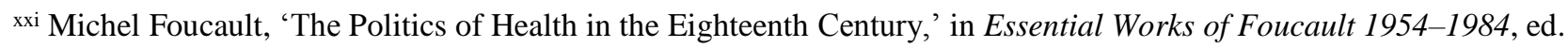
James D. Faubion (London: Penguin, 2002), 90-105, particularly 99.

xxii Stein, 'Bureaucracy.' (see note 11); María Concepción Gavira Márquez, 'Instrucciones para los subdelegados de la intendencia de Potosi realizadas por el intendete Juan del Pino Marnrique en 1784,' Diálogo Andino 42 (2003): 5-16. xxiii Real Ordenanza para el establecimiento e instrucción de intendentes de ejército y provincia en el Virreinato de Buenos-Aires (Madrid: Imprenta Real, 1782), 56 (article 54).

${ }^{\text {xxiv }}$ Ordenanza de Intendentes (1782), 63 (article 60) (see note 23). The setting of low costs lodgings for the travellers to incentivise commerce was first required in the first set of laws for colonisation and urban planing in the colonies known as Leyes de Indias, see Ley 18, title 2, book 5 as well as Ley 1, title 17, book 4.

${ }^{x x v}$ Ordenanza de Intendentes (1782), 67 (article 64) (see note 23).

xxvi Murray, 'Disciplining Buenos Aires' (see note 13).

${ }^{\mathrm{xxvii}}$ The first Viceroy of the River Plate was appointed by Royal Order of the 1 August 1776. The Viceroyalty was established, as the order decreed, completely independent of the Viceroyalty of Peru, to which the River Plate region formerly belonged. Archivo General de la Nación Argentina [General Archive of Argentina Nation] (Buenos Aires, Argentina) = AGNA, Documentos referentes a la guerra de la independencia y emancipación política de la República Argentina y de otras secciones de América a que cooperó desde 1810 hasta 1828, 3 vol.s (Buenos Aires, 1914), I: 17-9. xxviii Several urban improvements were made under the time of the second Viceroy of Buenos Aires, Juan José Vértiz y Salcedo (1778-1784). See Archivo General de Indias [General Archive of the Indies] (Seville, Spain) = AGI, Mapas $y$ Planos, Libros Manuscritos, 60, ff. 34-35, Memorias del gobierno del Virrey Vértiz, 12 March 1784.

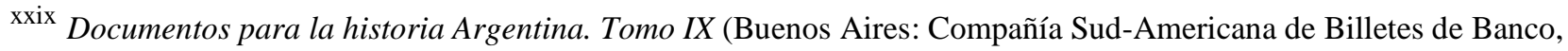
1918), 306. 
${ }^{\mathrm{xxx}}$ Francisco de Paula Sanz, Bando del Superintendente de Paula Sanz sobre calles y edificios, 28 July 1784, in Documentos para la historia Argentina, 74-75 (see note 29).

${ }^{x x x i}$ It is not known why the applications suddenly stop in 1792. No more files have been found in the archives and there are no records stating that the regulation was discontinued before the end of the colonial period (1810). It is possible that the law did not change and planning permissions were requested but the files have been misplaced or lost.

xxxii Abbot Laugier quoted in Barry Bergdoll, European Architecture 1750-1890 (Oxford: Oxford University Press, 2000), 49.

xxxiii Carlos Sambricio, Territorio y ciudad en la España de la ilustración (Madrid, Ministerio Obras Públicas y Transporte, 1991).

${ }^{\text {xxxiv }}$ AGI (see note 29), Estado 46, doc. 35, the Governor of the Philippines Rafael María de Aguilar to the Príncipe de la Paz, Manila, 28 February 1797.

${ }^{\mathrm{xxxv}}$ European examples of this ideal urbanism can be found in France in the different royal squares such as Place des Vosges (1612), Place Vêndome (about 1700), Place des Victories and in England the most finished examples are the Royal Crescent and the Royal Circus developed by John Nash in Bath. See John Summerson, The Architecture of the Eighteenth Century (London: Thames \& Hudson, 1986), 162 and Sigfried Gideon, Space, Time and Architecture: The Growth of a New Tradition (Cambridge: Harvard University Press, 1942), 142-3.

xxxvi Quoted in Sambricio, Territorio y ciudad, 216 (see note 33).

xxxvii Murray, 'Disciplining Buenos Aires' (see note 13).

xxxviii Quoted in Bergdoll, European Architecture, 48 (see note 32).

xxxix Quoted in Fernando Chueca y Goitía, 'Madrid y las reformas de Carlos III,' in Urbanismo e historia urbana en el mundo hispano, 2 vol.s, ed. Antonio Bonet Correa (Madrid: Dosal, 1982), II: 927-38, particularly 928.

${ }^{x 1}$ See Juan Manuel de San Vicente, 'Exacta descripción de la magnífica corte mexicana.' Anales del Museo Nacional de Arqueología, Historia y Etnología 5 (1913): 5-40.

${ }^{x l i}$ AGI (see note 29), Mexico 1433, doc. 481, testimonio, State of Mexico City 1792-1793.

xlii Quoted in Bergdoll, European Architecture, 49 (see note 32).

xliii Richard Sennett, The Fall of Public Man (London: Faber and Faber, 1977).

xliv Quoted in Chueca y Goitía, 'Madrid y las reformas,' 938 (see note 39).

${ }^{x l v}$ Humberto Rodríguez Camilloni, 'Manuel de Amat y Junyent y la Navona de Lima: un ejemplo de diseño urbano barroco del siglo XVIII en el virreinato del Perú,' Anales del Instituto de Investigaciones Estéticas 74-75 (1999): 14776.

xlvi Carrió de la Vandera, A. (1997) El Lazarillo de los ciegos caminantes. Buenos Aires: Emecé

${ }^{x l v i i}$ AGNA (see note 27), Sala IX, División colonia, Permisos para edificar, legajo 11.1.2, doc. 248, 1792.

xlviii'María Luz López Terrada and Àlvar Martinez Vidal, 'El Tribunal del Real Protomedicato en la Monarquia

Hispanica (1593-1808). Presentacion,' Dynamis: Acta Hispanica ad Medicinae Scientiarumque Historiam Illustrandam

16 (1996): 17-9.

xlix Pilar Gardeta Sabater, 'El Nuevo Modeo del Real Tribunal del Protomedicato en la America Espanola:

Transformaciones Sufridas Ante las Leyes de Indias y El Cuerpo Legislativo Posterior,' Dynamis: Acta Hispanica ad Medicinae Scientiarumque Historiam Illustrandam 16 11896f: 297-59. 
${ }^{1}$ AGI (see note 28), Mapas y Planos, Libros Manuscritos, 60, ff. 34-35, Memorias del gobierno del Virrey Vértiz, 12 March 1784.

li Martin Jouve, The Black Doctors of Colonial Lima, Science, Race and Writing in Colonial and Early Repubican Peru. Canada: McGill-Queen's University Press, 2014.

lii Carlos Di Pasquo, Graciela S. Fumbarg and Sara Vaisman, 'La organizacion Funcional de los Hospitales en la Arquitectura Hispanoamericana del Siglo XVII,' Anales del Instituto de Arte Americano e Investigaciones Estéticas 'Mario J. Buschiazzo' 35-36 (2001): 47-84. 